To Cite: Tok H, Ertaş N, 2021. The Effects of Germinated Seeds on Nutritional and Technological Properties of Bread. Journal of the Institute of Science and Technology, 11(2): 1183-1193.

Atıf için: Tok H, Ertaş N, 2021. Çimlenmiş Tohumların Ekmeğin Beslenme ve Teknolojik Özellikleri Üzerine Etkileri. Iğdır Üniversitesi Fen Bilimleri Enstitüsü Dergisi, 11(2): 1183-1193.

\title{
The Effects of Germinated Seeds on Nutritional and Technological Properties of Bread
}

$$
\text { Hatice TOK }{ }^{1} \text {, Nilgün ERTAŞ }{ }^{1 *}
$$

\begin{abstract}
In this study, wheat, rye and green lentil seeds were germinated at different germination period (1, 3 and 5 days), dried and ground into flour. Germinated seed flours were substituted for wheat flour at different ratios $(0,5,10$ and $15 \%)$ in bread making; it was carried out in order to increase nutritional and functional properties of bread. As the germination period increased, L* values of germinated seed flour decreased, $a^{*}, b^{*}$ and chroma values increased. The highest protein value was observed in germinated green lentils. Increase germination time resulted in increase in the ash content and minerals (calcium, magnesium and iron) and decrease in phytic acid. Increase in the level of supplementation of germinated flour in bread making, decrease in $\mathrm{L}^{*}$ and hue angle values, increase in $\mathrm{a}^{*}$, $b^{*}$ and saturation index values were observed. Soft bread crumb were observed at the 3rd day hardness with using $15 \%$ germinated seed flour. The highest phytic acid value among the bread samples was observed with control bread samples. Using all germinated flours in formulation led to a higher total phenolic content than control sample. Among the bread samples, the highest calcium, magnesium and phosphorus values of bread samples were obtained with germinated rye flour addition. The highest iron and potassium values were observed with green lentil flour addition. The $5 \%$ substitution rate was defined as an acceptable value in terms of bread volume and specific volume values.
\end{abstract}

Keywords: Germination, bread, phytic acid, phenolic, functional properties

\section{Çimlenmiş Tohumların Ekmeğin Beslenme ve Teknolojik Özellikleri Üzerine Etkileri}

ÖZET: Bu çalışmada buğday, çavdar ve yeşil mercimek farklı sürelerde (1, 3 ve 5 gün) çimlendirilmiş, kuturulmuş ve un haline getirilmiştir. Çimlenmiş tohum unları ekmeğin besinsel ve fonksiyonel özelliklerini geliştirmek amaciyla buğday unu yerine farklı oranlarda $(\% 0,5,10$ ve 15$)$ yer değiştirilerek kullanılmıştır. Çimlenme süresi arttıkça çimlenmiş tohum unu $\mathrm{L} *$ değerleri azalırken $\mathrm{a} *, \mathrm{~b} *$ ve chroma değerleri artmıştır. En yüksek protein değeri çimlendirilmiş yeşil mercimeklerde gözlenmiştir. Artan çimlenme süresi, kül ve mineral değerlerinde (kalsiyum, magnezyum ve demir) artmaya, fitik asit değerinde ise azalmaya sebep olmuştur. Ekmek örneklerinde artan çimlenmiş tohum unları ile parlaklık ve hue angle değerlerinde bir azalma, kırmızılık, sarılık ve saturation index değerlerinde bir artış gözlenmiştir. \%15 çimlenmiş tohum unu içeren ekmek örneklerinde daha düşük 3. gün sertlik değeri elde edilmiştir. En yüksek fitik asit değeri kontrol örneğinde belirlenmiş̧ir. Ekmek formülasyonuna çimlenmiş tohum unu ilavesi ile kontrol örnekten daha yüksek toplam fenolik madde içeriği elde edilmiştir. En yüksek kalsiyum, magnezyum ve fosfor değeri çavdar içeren ekmek örneklerinde belirlenirken en yüksek demir ve potasyum değeri yeşil mercimek unu ilavesiyle bulunmuştur. Ekmek hacim ve spesifik hacim değerleri açısından değerlendirildiğinde $\% 5$ kullanım oranı kabul edilebilir olarak belirlenmiştir.

Anahtar Kelimeler: Çimlendirme, ekmek, fitik asit, fenolik, fonksiyonel özellikler

${ }^{1}$ Hatice TOK (Orcid ID: 0000-0002-8982-6428), Nilgün ERTAŞ (Orcid ID: 0000-0002-0671-2485), Necmettin Erbakan University, Engineering and Architecture Faculty, Food Engineering Department, Konya,Turkey

*Sorumlu Yazar/Corresponding Author: Nilgün ERTAŞ, e-mail: dr.nilgünertas@gmail.com

This study was supported by the Necmettin Erbakan University Research Foundation (Project number: 161319017). 


\section{INTRODUCTION}

Germinating is whole of the metabolic activities enabling the breakdown of proteins, the oxidation of lipids and the simplification of carbohydrates to supply some necessary essential components and energy for the development and growth of plants. Germination begins with the intake of water by the dormant dry seed and usually ends with root emergence (Bewley and Black, 1994).

One of the most important reasons for this is that the germination process is not expensive and the other is that it does not require complicated equipment. While germination of seeds, especially wheat and some cereals such as barley and oat is a common practice today, alfalfa, broccoli, soybean, chickpea, clover, pea and some other cereal grains are germinated and consumed as sprouts (Yetim et al., 2010).

Pea, lentil, bean (Kuo et al., 2004), cowpea, chickpea and mung bean (Ghavidel and Prakash, 2007), rye (Katina et al., 2007), rice (Kim et al., 2012), lupine (Ertaş, 2015), were used among the studies on the nutritional changes of the germination.

When germinated seed compared with raw seeds; it seems to have higher vitamin content, higher phenolic substance, higher quality protein, higher amount of aromatic amino acids and more polyunsaturated fatty acids (Öztürk, 2008). Considerable increase in the amount of bioactive compounds such as dietary fiber, magnesium, zinc, potassium, tocotrienols, prolylendopeptidase inhibitor gamma aminobutyric acid, $\gamma$-oryzanol and ferulic acid were reported by Kayahara et al. (2000) in germinated brown rice. After germination of seed, the amount of triglycerides and energy in the dry matter decreased; ash, crude fiber, diglycerides, some amino acids and mineral substances increased in comparison to raw seed and the amount of phytic acid decreased by about 25\% (Sung et al., 2005). A decrease in trypsin inhibitor activity is resulted by germination including soybeans, bean (Sangronis and Machado, 2007), and peas (Urbano et al., 2005).

It has been found that the amount of anti-nutrients decrease during germination and after germination the compounds that useful for health and phytochemical properties are formed, the increase in amino acids and ascorbic acid contribute to the bioavailability of trace minerals. It is stated that these substances plays important role for preventing many diseases and beneficial effects on blood pressure and central nervous system. Thus, functional foods that produced by germination can be improved for enhance our health (Sangronis and Machado, 2007).

In this research, seeds such as wheat, rye and green lentils were germinated, dried and ground. The germinated flours were used in breadmaking process by application as different ratios to amplify functional and nutritional characteristics of bread.

\section{MATERIALS AND METHODS}

\section{Material}

Wheat, rye and green lentil were purchased from common suppliers in Konya to germinate. All purpose wheat flour, bakers' yeast (Saccharomyces cerevisiae) and salt were used for bread making. Amount of water required for bread making was previously determined by a farinograph until the mixing curve reached 500 BU. Germination was done according to the jar method. In the jar method; $100 \mathrm{~g}$ seeds were placed in $500 \mathrm{ml}$ of $0.07 \%$ sodium hypochlorite $(\mathrm{NaClO})$ for 30 minutes and then washed 10 times with distilled water to neutralize $\mathrm{pH}$ and filtered with the excess water. Then the seeds were soaked in $1000 \mathrm{ml}$ distilled water for 5 hours and shaken for 30 minutes so as to draw water. The jars were covered with thin cheesecloth so that the seeds were contacted with air. Then water (kernels: water ratio of 1:2) was added. After several times rinsing, the water was removed from the jar. The seeds were germinated at room temperature in the dark with watering every $12 \mathrm{~h}$. At the 
end of 1, 3 and 5 days, germinated seeds were dried in $50{ }^{\circ} \mathrm{C}$ (Nuve FN-400) and grounded in a hammer mill. Ungerminated seeds were used as control group.

\section{Experimental design}

The experiment consists of three steps. The first step was to germinate the 3 different seeds (wheat, rye and green lentil) in 4 different germination times (0, 1, 3 and 5 days), to dry and grind, to choose the best germination period according to some physical and sensorial parameters and this step was carried out in duplicate according to the $(4 \times 3) \times 2$ trial pattern. In the second step, in the germinated seeds samples, 5-day germination time chosed the best germination period and these germinated seeds were grinded, germinated seed flours were added to wheat flour at 4 different addition level $(0,5,10$ and $15 \%)$, bread experiments were made at these rates, and physical, chemical, nutritional and sensorial quality characteristics of the breads were determined in the second step. Four different addition levels $(0,5,10$ and $15 \%)$ of 3 different germinated cereal and legume flour (wheat, rye and green lentils) were used in bread production and second stage of the study was carried out in duplicate according to the $(3 \times 4) \times 2$ trial pattern. Then, nutritional properties were determined in the bread samples with the best technological features, in a single dose (15\%) of 3 different cereal and leguminous flour (wheat, rye and green lentil) bread samples and control bread sample with two replications according to the $4 \times 2$ trial pattern and samples were compared with each other.

\section{Assessment of seed germination}

At the end of the germination the sprout length was measured using electronic calipers. Germination rate index is calculated using the following formula;

$$
\mathrm{GRI}=\frac{\mathrm{N} 1}{\mathrm{G} 1}+\frac{\mathrm{N} 2}{\mathrm{G} 2}+\cdots+\frac{N n}{\mathrm{Gn}}
$$

GRI $=$ Germination rate index

$\mathrm{N} 1, \mathrm{~N} 2, \ldots, \mathrm{Nn}=$ number of seeds germinated

$\mathrm{G} 1, \mathrm{G} 2, \ldots, \mathrm{Gn}=$ Days of first count and days of last count

The germinated and non-germinated grains were counted and the yield was calculated as \% (Maguire, 1962).

\section{Bread making procedures}

Straight dough method for breadmaking (AACCI Approved 10-10.03 with some modifications) was carried out. The formulation based on flour weight, was used: $200 \mathrm{~g}$ flour (14\% $\mathrm{mb}), 3 \%$ compressed yeast, $1.5 \%$ salt, and water up to $500 \mathrm{BU}$ consistency. The dough was mixed with Hobart mixer (Hobart UK, London), divided into two equal parts, manually shaped, placed in tin pans to fermented at $65-70 \%$ humidity and $25 \pm 1{ }^{\circ} \mathrm{C}$ for $30 \mathrm{~min}$. Doughs were folded by passing through a cylinder and then fermented at $65-70 \%$ humidity and $25 \pm 1{ }^{\circ} \mathrm{C}$ for $30 \mathrm{~min}$ again. Doughs were folded by passing through a cylinder and by giving a circle shape for proofing $60 \mathrm{~min}$. The doughs were baked in oven (Arçelik ARMD-580, İstanbul, Türkiye) for $15 \mathrm{~min}$ at $250{ }^{\circ} \mathrm{C}$. The bread quality features were evaluated after $2 \mathrm{~h}$ of cooling at room temperature. Bread quality characteristics included: weight, volume (determined by seed displacement method), specific volume (by dividing bread volume by bread weight), crumb color, crust color and crumb hardness (Pyler, 1988). Breads baked in two different pans were analyzed in duplicate and averaged. After 24 hours, pore structure, symmetry and textural score were evaluated (between 1-5 points).

In breadmaking experiments, the flours of germinated cereal and legume grains (at the end of the 5th day of germination period) were added at the rate of $0,5,10$ and $15 \%$ according to the flour basis. 


\section{Color measurements}

A glass pyrex petri dish was placed between the surface of the flour samples (germinated cereal and legume seeds) and five different point of crumb and crust color of bread samples on the basis of CIELAB colour system was carried out using the CR-400 Chroma Meter (Konica Minolta Sensing, Inc., Osaka, Japan). L* measures luminosity, between black and white, a* measures the red coloration, $b^{*}$ measures the yellow colorant of foods.

\section{Analytical methods}

The proximate composition includes moisture contents (AACC method 44-12), ash contents (AACC Method 08-01.01), protein contents (AACC Method 46-12.01) of the samples were evaluated (AACC, 1990).

\section{Nutritional analysis}

Phytic acid content of the samples were measured as described in Haug and Lantzsch (1983) by colorimetric ferric precipitation method. Minerals as calcium, magnesium potassium phosphorus zinc and iron were determined in samples using a ICP-AES (Varian-Vista, Switzerland) by spectroscopic method as introduced by Skujins (1998). Total phenolic content was measured by the Folin-Ciocalteu colorimetric method as described by Beta et al., (2005).

\section{Statistical analysis}

Commercial software program (JMP, version 5.0) was used to perform statistical analyses. Data were subjected to statistical analysis of variance with two ways ANOVA and multiple comparison test $(\mathrm{P}<0.05)$ were performed to comparison of mean values. One way analysis of variance (ANOVA), followed by Tukey HSD test was used to evaluate differences between bread samples for nutritional analysis data at a level of significance $\mathrm{P}<0.05$.

\section{RESULTS AND DISCUSSION}

Anova results of the seeds and day of germination on the composition of seed and germinated seed flours and addition level on the properties of bread samples are shown in Table 1.

\section{Germinated seeds properties}

Effects of seeds and germination period on the germination parameters are shown in Table 2. While the highest yield value was obtained with rye sample, wheat and green lentil samples gave 55.00 and $51.50 \%$ yield values, respectively. After 5 day germination period, all grain seeds were germinated and the yield value was reached to $100 \%$. Also germinated rye seeds showed the highest sprout length and germination rate index compared to germinated wheat and green lentil seeds. Rye seeds showed the best and fastest germination performance among the seeds. The lowest grass size and germination rate index were obtained with green lentil seeds. Increasing germination period increased the yield, grass size and germination rate index.

Germinated wheat flour (GWF) gave the highest lightness values while germinated rye flour (GRF) showed the highest redness values, the highest yellowness, SI and hue angle values were obtained with germinated green lentil flour (GGLF). After 5 day germination period, lightness (L*) values decreased, while the redness $\left(a^{*}\right)$, yellowness $\left(b^{*}\right)$ and chroma values increased (Table 1). The increase in chroma value could be due to the increase in reducing sugar content during germination. Similar results were observed by Öztürk (2008) that after germination of wheat, L* values decreased, $\mathrm{a}^{*}$ and $\mathrm{b}^{*}$ values increased. 
Table 1. Anova results of the seeds and day of germination on the composition of seed and bread samples.

\begin{tabular}{|c|c|c|c|}
\hline \multirow{2}{*}{$\begin{array}{l}\text { Composition of seed } \\
\text { samples }\end{array}$} & \multicolumn{3}{|c|}{ F values } \\
\hline & Seeds (A) & Day of germination (B) & Interaction effect between $\mathrm{A}$ and $\mathrm{B}$ \\
\hline Yield (\%) & $57.61 * *$ & $4170.31 * *$ & $33 * *$ \\
\hline Grass size $(\mathrm{mm})$ & $102.04 * *$ & $1796.2 * *$ & $85.10 * *$ \\
\hline Germination rate index & $384.65 * *$ & $2501.57 * *$ & $58.82 * *$ \\
\hline $\mathrm{L}^{*}$ & $560.97 * *$ & $1763.94 * *$ & $478.83 * *$ \\
\hline$a^{*}$ & $321.69 * *$ & $55.24 * *$ & $23.70 * *$ \\
\hline$b^{*}$ & $1232.96 * *$ & $47.64 * *$ & $146.7 * *$ \\
\hline SI & $1215.28 * *$ & $49.73 * *$ & $148.05^{* *}$ \\
\hline Hue angle & $379.83 * *$ & $14.09 *$ & $15.48 * *$ \\
\hline Moisture (\%) & $162.57 * *$ & $603.54 * *$ & $182.7 * *$ \\
\hline $\operatorname{Ash}(\%)$ & $1369.02 * *$ & $36.27 * *$ & $22.51 * *$ \\
\hline Protein $(\%)$ & $4518.7 * *$ & $89.76 * *$ & $93.52 * *$ \\
\hline TPC (mg GAE kg $\left.{ }^{-1}\right)$ & $30601.99 * *$ & $16491.62 * *$ & $209.96 * *$ \\
\hline Phytic acid (mg $\left.100 \mathrm{~g}^{-1}\right)$ & $91.65^{* *}$ & $528.83 * *$ & $15.30 * *$ \\
\hline Calcium & $11691410 * *$ & $4661265^{* *}$ & $3419314 * *$ \\
\hline Magnesium & $4034923 * *$ & $9454499 * *$ & $5794465 * *$ \\
\hline Potassium & $4.1672 \mathrm{e} 8 * *$ & $4240213 * *$ & $4450172 * *$ \\
\hline Phosphorus & $17744049 * *$ & $1194227 * *$ & $1356357 * *$ \\
\hline Zinc & $72056.47 * *$ & $19616.29 * *$ & $10822.75 * *$ \\
\hline Iron & $617217.9 * *$ & $10267.98 * *$ & $17228.19 * *$ \\
\hline \multirow[t]{2}{*}{ Properties of bread samples } & \multicolumn{3}{|c|}{ F values } \\
\hline & Germinated Seeds Flours (A) & Addition Level (\%) (B) & Interaction effect between A and B \\
\hline Crumb color $\mathrm{L}^{*}$ & $12.11^{*}$ & $67.74 * *$ & $5.10^{*}$ \\
\hline Crumb color $\mathrm{a}^{*}$ & $24.33 * *$ & $69.24 * *$ & $4.61^{\mathrm{ns}}$ \\
\hline Crumb color $b^{*}$ & $287.30 * *$ & $76.57 * *$ & $75.03 * *$ \\
\hline Crumb color SI & $288.29 * *$ & $80.35 * *$ & $75.63 * *$ \\
\hline Crumb color Hue angle & $16.81^{*}$ & $42.27 * *$ & $2.65^{\mathrm{ns}}$ \\
\hline Crust color $\mathrm{L}^{*}$ & $19.78^{*}$ & $17.67 *$ & $4.56^{\mathrm{ns}}$ \\
\hline Crust color a* & $33.71 * *$ & $5.63^{\mathrm{ns}}$ & $4.57^{\mathrm{ns}}$ \\
\hline Crust color $\mathrm{b}^{*}$ & $52.40 * *$ & $10.78^{*}$ & $7.55^{*}$ \\
\hline Crust color SI & $59.53 * *$ & $11.36^{*}$ & $7.49 *$ \\
\hline Crust color Hue angle & $4.40 *$ & $2.21^{\mathrm{ns}}$ & $3.38^{*}$ \\
\hline Weight $(\mathrm{g})$ & $61.83 * *$ & $223.86 * *$ & $3.41 *$ \\
\hline Volume (ml) & $0.87^{\mathrm{ns}}$ & $266.18 * *$ & $4.16^{*}$ \\
\hline Specific volume (g/ml) & $7.60 *$ & $370.06 * *$ & $5.11 *$ \\
\hline Pore $(1-5)$ & $285.96^{* *}$ & $259.59 * *$ & $48.00 * *$ \\
\hline Symmetry (1-5) & $315.53 * *$ & $267.49 * *$ & $72.23 * *$ \\
\hline Texture (1-5) & $321.91 * *$ & $292.85 * *$ & $76.62 * *$ \\
\hline Hardness $(24 h)(g)$ & $58.88 * *$ & $80.17 * *$ & $24.73 * *$ \\
\hline Hardness (72h) (g) & $45.23 * *$ & $485.09 * *$ & $39.61 * *$ \\
\hline
\end{tabular}

ns: no significance. *Significant at $p<0.05$ respectively. $* *$ Significant at $p<0.01$, respectively

Chemical and nutritional evaluation of germinated seeds flours are shown in Table 3. According to ANOVA results germinated seeds and germination period factors affected the moisture, ash, protein, phytic acid and total phenolic content $(\mathrm{p}<0.01)$ statistically. GRF gave the highest moisture content (10.06\%), while GWF and GGLF gave lower and statistically similar ash values. The moisture contents of germinated seeds decreased from 11.03 to $7.10 \%$ after 3 day germination, and then increased from 7.10 to $10.47 \%$ after 5 day germination. The highest ash content $(2.80 \%)$ obtained with GGLF and the lowest ash content determined with GWF.

Increasing germination period increased the ash content of germinated seeds and the highest ash content was obtained after 5 day germination period. GGLF showed the highest protein content among the samples. This is due to its high protein content of legumes compared to the cereals. It can be observed that germination increased the protein content. Among the germinated grains, the higest total phenolic content (3377 $\mathrm{mgGAE} \mathrm{kg}^{-1}$ ) was identified with GGLF. Also after 5 day germination, the 
total phenolic content increased as $57.17 \%$. During germination the highest increase $(104.95 \%)$ were observed with GGLF. Similar results were reported by Zilic et al. (2014) that the total phenolic content of 5 day germinated wheat sample was increased from 1431 to $1627 \mathrm{mgGAE} \mathrm{kg-1.} \mathrm{Also} \mathrm{an} \mathrm{increase} \mathrm{in}$ total phenolic content in germinated rye sample compared to raw rye sample reported before by Katina et al. (2007). The lowest phytic acid content was determined with GRF, while the highest was GGLF.

Table 2. Effect of seeds and period on germination parameters and color properties

\begin{tabular}{|c|c|c|c|c|c|c|c|c|}
\hline & $\begin{array}{c}\text { Yield } \\
(\%)\end{array}$ & $\begin{array}{c}\text { Grass size } \\
\quad(\mathbf{m m})\end{array}$ & $\begin{array}{c}\text { Germination rate } \\
\text { Index }\end{array}$ & $\mathbf{L}^{*}$ & $\mathbf{a}^{*}$ & $\mathbf{b}^{*}$ & SI & Hue angle \\
\hline \multicolumn{9}{|l|}{$\overline{\text { Seeds }}$} \\
\hline GWF & $55.00 \pm 47.8^{\mathrm{b}}$ & $8.90 \pm 12.61^{\mathrm{b}}$ & $28.92 \pm 26.78^{\mathrm{b}}$ & $82.73 \pm 4.17^{\mathrm{a}}$ & $1.33 \pm 1.01^{\mathrm{b}}$ & $12.33 \pm 2.43^{\mathrm{c}}$ & $12.42 \pm 2.46^{\mathrm{c}}$ & $83.68 \pm 1.98^{\mathrm{b}}$ \\
\hline GRF & $61.50 \pm 44.69^{\mathrm{a}}$ & $12.25 \pm 17.99^{\mathrm{a}}$ & $43.46 \pm 36.29^{a}$ & $79.32 \pm 6.22^{\mathrm{b}}$ & $2.11 \pm 0.53^{\mathrm{a}}$ & $13.65 \pm 3.32^{\mathrm{b}}$ & $13.81 \pm 3.35^{\mathrm{b}}$ & $81.10 \pm 1.29^{c}$ \\
\hline GGLF & $51.50 \pm 47.07^{\mathrm{c}}$ & $6.50 \pm 8.33^{c}$ & $23.25 \pm 22.51^{\mathrm{c}}$ & $79.51 \pm 2.35^{\mathrm{b}}$ & $-0.75 \pm 1.05^{\mathrm{c}}$ & $21.40 \pm 2.46^{\mathrm{a}}$ & $21.43 \pm 2.44^{\mathrm{a}}$ & $92.06 \pm 2.98^{\mathrm{a}}$ \\
\hline \multicolumn{9}{|c|}{ Day of germination } \\
\hline 0 & $0.00 \pm 0.00^{\mathrm{d}}$ & $0.00 \pm 0.00^{\mathrm{d}}$ & $0.00 \pm 0.00^{\mathrm{d}}$ & $83.41 \pm 3.97^{\mathrm{a}}$ & $0.14 \pm 1.18^{\mathrm{d}}$ & $14.60 \pm 8.32^{\mathrm{c}}$ & $14.66 \pm 8.28^{c}$ & $85.99 \pm 5.34^{\mathrm{ab}}$ \\
\hline 1 & $28.00 \pm 14.37^{\mathrm{c}}$ & $1.03 \pm 0.08^{c}$ & $14.00 \pm 7.18^{c}$ & $83.12 \pm 3.73^{\mathrm{a}}$ & $0.85 \pm 1.79^{b}$ & $15.61 \pm 4.00^{\mathrm{b}}$ & $15.73 \pm 3.97^{\mathrm{b}}$ & $85.78 \pm 6.44^{\mathrm{b}}$ \\
\hline 3 & $96.00 \pm 4.06^{\mathrm{b}}$ & $6.00 \pm 1.10^{\mathrm{b}}$ & $45.50 \pm 15.18^{\mathrm{b}}$ & $80.62 \pm 0.43^{\mathrm{b}}$ & $0.56 \pm 1.74^{\mathrm{c}}$ & $15.66 \pm 3.44^{b}$ & $15.75 \pm 3.42^{\mathrm{b}}$ & $86.85 \pm 6.26^{\mathrm{a}}$ \\
\hline 5 & $100.00 \pm 0.00^{\mathrm{a}}$ & $29.83 \pm 9.68^{\mathrm{a}}$ & $68.00 \pm 15.18^{\mathrm{a}}$ & $74.93 \pm 3.53^{\mathrm{c}}$ & $1.78 \pm 0.88^{\mathrm{a}}$ & $17.29 \pm 2.74^{\mathrm{a}}$ & $17.41 \pm 2.69^{\mathrm{a}}$ & $85.83 \pm 3.23^{\mathrm{a}}$ \\
\hline
\end{tabular}

Table 3. Chemical and nutritional evaluation of germinated seeds flours

\begin{tabular}{|c|c|c|c|c|c|}
\hline Seeds & Moisture (\%) & Ash (\%) & Protein $(\%)$ & TPC (mgGAE kg-1) & Phytic acid $\left(\mathrm{mg}^{100 \mathrm{~g}^{-1}}\right)$ \\
\hline GWF & $8.45 \pm 3.03^{\mathrm{b}}$ & $1.26 \pm 0.34^{\mathrm{c}}$ & $13.46 \pm 1.45^{\mathrm{b}}$ & $2056 \pm 605^{\mathrm{c}}$ & $866 \pm 411^{b}$ \\
\hline GRF & $10.06 \pm 2.33^{\mathrm{a}}$ & $1.83 \pm 0.09^{\mathrm{b}}$ & $13.00 \pm 2.02^{\mathrm{c}}$ & $2665 \pm 522^{b}$ & $654 \pm 305^{\mathrm{c}}$ \\
\hline GGLF & $8.52 \pm 1.54^{\mathrm{b}}$ & $2.80 \pm 0.08^{\mathrm{a}}$ & $22.66 \pm 0.36^{\mathrm{a}}$ & $3377 \pm 436^{\mathrm{a}}$ & $963 \pm 514^{\mathrm{a}}$ \\
\hline \multicolumn{6}{|c|}{ Day of germination } \\
\hline 0 & $11.03 \pm 0.73^{\mathrm{a}}$ & $1.75 \pm 0.88^{\mathrm{c}}$ & $15.31 \pm 5.56^{\mathrm{c}}$ & $2185 \pm 678^{d}$ & $1251 \pm 217^{\mathrm{a}}$ \\
\hline 1 & $7.45 \pm 0.80^{\mathrm{c}}$ & $1.99 \pm 0.65^{\mathrm{b}}$ & $17.16 \pm 4.87^{\mathrm{a}}$ & $2347 \pm 594^{c}$ & $1136 \pm 228^{b}$ \\
\hline 3 & $7.10 \pm 2.31^{\mathrm{d}}$ & $2.05 \pm 0.66^{\mathrm{b}}$ & $15.98 \pm 5.00^{\mathrm{b}}$ & $2818 \pm 638^{\mathrm{b}}$ & $593 \pm 160^{c}$ \\
\hline 5 & $10.47 \pm 2.27^{\mathrm{b}}$ & $2.07 \pm 0.63^{\mathrm{a}}$ & $17.05 \pm 4.62^{\mathrm{a}}$ & $3434 \pm 458^{\mathrm{a}}$ & $331 \pm 25^{\mathrm{d}}$ \\
\hline
\end{tabular}

During germination phytic acid decreased, so the lowest phytic acid values were observed after 5 day germination period. This is due to the increasing activity of phytase enzyme in germination. At the end of the germination period of approximately 7-8 days, the complete phytate content disintegrated is reported (Ashton and Williams, 1958). In this study, the loss of phytic acid content of GRF, GWF and GGLF were 65,74 and $79 \%$ after 5 day germination, respectively. The primary task of phytase in germinated grains is to provide inorganic phytate phosphate in the early stages of germination (Frolich et al., 1988). The enzymatic hydrolysis of the phytate in seed has great prospects for phosphorus metabolism during the germination of cereals. Ghavidel and Prakash (2007) reported that the phytic

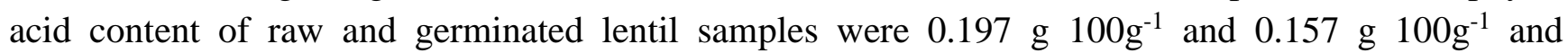
decreased during germination. Germination resulted the degradation of phytic acid thus, bioavailability of minerals and proteins increase.

The mineral contents of germinated seed flours are shown in Table 4. According to ANOVA results, the variation of seed and germination period had significant $(p<0.01)$ effect on the mineral content. The highest calcium, potassium, phosphorus, zinc and iron content were observed with germinated green lentil seeds. Germinated rye seeds gave the highest magnessium values. During the gemination period calcium, magnessium and iron content increased by increasing germination time. 
While potassium, phosphorus and zinc content of the germinated seeds increased until the $3^{\text {rd }}$ day of the germination, and then decreased.

Table 4. Mineral content of geminated seeds flour $\left(\mathrm{mg} 100 \mathrm{~g}^{-1}\right)$

\begin{tabular}{lcccccc}
\hline Seeds & Calcium & Magnesium & Potassium & Phosphorus & Zinc & Iron \\
\hline GWF & $71.92 \pm 12.06^{\mathrm{c}}$ & $132.57 \pm 55.20^{\mathrm{c}}$ & $319.49 \pm 96.57^{\mathrm{c}}$ & $264.53 \pm 66.88^{\mathrm{c}}$ & $1.92 \pm 0.82^{\mathrm{c}}$ & $2.23 \pm 0.64^{\mathrm{c}}$ \\
GRF & $84.89 \pm 15.19^{\mathrm{b}}$ & $160.39 \pm 19.54^{\mathrm{a}}$ & $521.17 \pm 44.28^{\mathrm{b}}$ & $358.01 \pm 18.31^{\mathrm{b}}$ & $3.05 \pm 0.57^{\mathrm{b}}$ & $3.17 \pm 0.50^{\mathrm{b}}$ \\
GGLF & $93.65 \pm 5.20^{\mathrm{a}}$ & $145.07 \pm 6.44^{\mathrm{b}}$ & $1016.26 \pm 51.11^{\mathrm{a}}$ & $432.38 \pm 23.08^{\mathrm{a}}$ & $3.38 \pm 0.39^{\mathrm{a}}$ & $6.58 \pm 0.80^{\mathrm{a}}$ \\
\hline Day of germination & & & & & \\
\hline 0 & $74.39 \pm 15.25^{\mathrm{d}}$ & $110.23 \pm 51.96^{\mathrm{d}}$ & $562.98 \pm 370.47^{\mathrm{d}}$ & $316.62 \pm 123.76^{\mathrm{d}}$ & $2.17 \pm 0.98^{\mathrm{d}}$ & $3.54 \pm 2.15^{\mathrm{d}}$ \\
1 & $81.62 \pm 9.68^{\mathrm{c}}$ & $151.06 \pm 8.43^{\mathrm{c}}$ & $611.97 \pm 302.22^{\mathrm{c}}$ & $350.58 \pm 74.46^{\mathrm{c}}$ & $3.05 \pm 1.26^{\mathrm{b}}$ & $3.94 \pm 1.48^{\mathrm{c}}$ \\
3 & $84.24 \pm 14.44^{\mathrm{b}}$ & $156.79 \pm 7.93^{\mathrm{b}}$ & $656.09 \pm 348.24^{\mathrm{a}}$ & $373.24 \pm 71.06^{\mathrm{a}}$ & $3.20 \pm 0.21^{\mathrm{a}}$ & $4.20 \pm 2.65^{\mathrm{b}}$ \\
5 & $93.68 \pm 13.55^{\mathrm{a}}$ & $165.95 \pm 21.52^{\mathrm{a}}$ & $644.85 \pm 273.27^{\mathrm{b}}$ & $366.13 \pm 43.80^{\mathrm{b}}$ & $2.72 \pm 0.35^{\mathrm{c}}$ & $4.30 \pm 2.08^{\mathrm{a}}$ \\
\hline For each parameter, means with similar letter in a colomn do not differ significantly between different germinated seed flours and addition level(p<0.05). GWF: Germinated \\
Wheat Flour, GRF: Germinated Rye Flour, GGLF: Germinated Green Lentil Flour.
\end{tabular}

\section{Quality Properties of Bread}

In the breadmaking process, the seeds germinated in 5-day were used. These germinated seeds were grinded to flour and substituted by wheat flour at 4 different addition levels $(0,5,10$ and $15 \%)$. The physical, chemical, nutritional and sensorial quality characteristics of the breads were determined. The highest $\mathrm{L}^{*}$ and hue angle values and the lowest $\mathrm{a}^{*}, \mathrm{~b}^{*}$ and SI values of bread crumb were measured with GGLF. GRF addition showed the highest redness while the GWF addition showed the highest yellowness values of bread crumb color. As can be seen in Table 5, increasing level of germinated flour showed the decrease in lightness and hue angle values and more matt appearance was obtained on bread samples, whereas an increase in the values of redness, yellowness and saturation index was detected. Similar result occurred in another study investigated by Herken (2007), when the level of germinated cowpea flour increased in pasta, lightness decreased. This result could be explained with lysine amino acid release as a result of germination. Ribose glucose, maltose and lactose, which is formed as a result of disintegration of starch, is caused by browning (Maillard reaction) as a result of combining, as well as free amino acids and peptides (Goesaert et al., 2005). In another study, the bread made with germinated chickpea flour exhibited the the darkest bread crumb, the $a^{*}$ value was high in germinated chickpea bread (Quazib et al., 2016).

Table 5. Crumb color values of bread samples produced with germinated seed flours

\begin{tabular}{|c|c|c|c|c|c|c|c|c|c|c|}
\hline & \multicolumn{5}{|c|}{ Crumb color } & \multicolumn{5}{|c|}{ Crust color } \\
\hline & $\mathbf{L}^{*}$ & a* & $\mathbf{b}^{*}$ & SI & Hue angle & $\mathbf{L}^{*}$ & $\mathrm{a}^{*}$ & $\mathbf{b}^{*}$ & SI & Hue angle \\
\hline \multicolumn{11}{|l|}{ GSF } \\
\hline GWF & $65.79 \pm 5.86^{\mathrm{ab}}$ & $1.34 \pm 0.95^{\mathrm{b}}$ & $21.70 \pm 5.58^{\mathrm{a}}$ & $21.75 \pm 5.60^{\mathrm{a}}$ & $86.58 \pm 2.25^{\mathrm{a}}$ & $47.70 \pm 4.72^{\mathrm{b}}$ & $10.80 \pm 1.61^{\mathrm{b}}$ & $15.16 \pm 2.85^{\mathrm{b}}$ & $18.63 \pm 3.14^{\mathrm{b}}$ & $54.34 \pm 3.00^{\mathrm{b}}$ \\
\hline GRF & $64.21 \pm 4.83^{\mathrm{b}}$ & $1.99 \pm 1.34^{\mathrm{a}}$ & $17.05 \pm 1.24^{\mathrm{b}}$ & $17.20 \pm 1.36^{\mathrm{b}}$ & $83.58 \pm 4.09^{b}$ & $45.82 \pm 5.19^{\mathrm{b}}$ & $10.47 \pm 1.06^{\mathrm{b}}$ & $14.76 \pm 3.64^{\mathrm{b}}$ & $18.16 \pm 3.39^{b}$ & $53.80 \pm 6.18^{b}$ \\
\hline GGLF & $67.58 \pm 2.89^{\mathrm{a}}$ & $0.96 \pm 0.63^{\mathrm{c}}$ & $14.87 \pm 0.89^{\mathrm{c}}$ & $14.91 \pm 0.87^{\mathrm{c}}$ & $86.23 \pm 2.50^{\mathrm{a}}$ & $51.84 \pm 2.19^{\mathrm{a}}$ & $13.33 \pm 1.00^{\mathrm{a}}$ & $21.37 \pm 2.70^{\mathrm{a}}$ & $25.21 \pm 2.70^{\mathrm{a}}$ & $57.90 \pm 2.26^{\mathrm{a}}$ \\
\hline \multicolumn{11}{|c|}{ Level (\%) } \\
\hline 0 & $70.88 \pm 0.30^{\mathrm{a}}$ & $0.21 \pm 0.02^{\mathrm{d}}$ & $15.88 \pm 0.55^{\mathrm{c}}$ & $15.88 \pm 0.55^{\mathrm{c}}$ & $89.25 \pm 0.07^{\mathrm{a}}$ & $53.31 \pm 0.69^{\mathrm{a}}$ & $12.21 \pm 0.28^{\mathrm{a}}$ & $18.78 \pm 0.37^{\mathrm{a}}$ & $22.39 \pm 0.4^{\mathrm{a}}$ & $56.97 \pm 0.53^{\mathrm{a}}$ \\
\hline 10 & $64.76 \pm 2.48^{\mathrm{c}}$ & $1.88 \pm 0.69^{\mathrm{b}}$ & $16.34 \pm 1.81^{\mathrm{c}}$ & $16.45 \pm 1.84^{\mathrm{c}}$ & $83.48 \pm 2.19^{c}$ & $45.58 \pm 4.96^{\mathrm{b}}$ & $10.84 \pm 2.58^{\mathrm{b}}$ & $14.84 \pm 5.30^{\mathrm{b}}$ & $18.46 \pm 5.56^{\mathrm{b}}$ & $52.84 \pm 7.06^{\mathrm{b}}$ \\
\hline 15 & $60.04 \pm 3.22^{\mathrm{d}}$ & $2.54 \pm 0.94^{\mathrm{a}}$ & $20.09 \pm 5.04^{\mathrm{a}}$ & $20.27 \pm 5.03^{\mathrm{a}}$ & $82.68 \pm 2.77^{\mathrm{c}}$ & $47.67 \pm 3.91^{\mathrm{b}}$ & $12.13 \pm 1.55^{\mathrm{b}}$ & $18.66 \pm 4.90^{\mathrm{a}}$ & $22.30 \pm 4.91^{\mathrm{a}}$ & $56.35 \pm 3.85^{\mathrm{ab}}$ \\
\hline
\end{tabular}

For each parameter, means with similar letter in a colomn do not differ significantly between different germinated seed flours and addition level(p<0.05). GWF: Germinated Wheat Flour, GRF: Germinated Rye Flour, GGLF: Germinated Green Lentil Flour. GSF:Germinated Seed Flour

In literature, crust color of bread, melanoidin content and antioxidant capacity values were depends on baking time, sugar content and temperature (Shen et al. 2018). The amylase activity in the germination can improve the overall digestion and absorption of products, and also increase reducing sugar content. The addition of GGLF gave the highest lightness, redness, yellowness, saturation index and hue angle values in bread crust color. GWF and GRF showed similar color properties according to 
lightness, redness, yellowness, SI and hue angle values. The increment in the addition level of germinated seed flours caused reduction in lightness and redness values. Shen et al. (2018) reported that breads containing sugar had less yellowish and darker crust color. In this study, addition the germinated seed flour up to $10 \%$ usage level showed a decrease in yellowness, saturation index and hue angle values, while more than $10 \%$ usage level of germinated seed flour caused a slight increase in these color properties.

Table 6. Effects of germinated seed flours and addition level on bread properties

\begin{tabular}{lcccccccc}
\hline & $\begin{array}{c}\text { Weight } \\
(\mathbf{g})\end{array}$ & $\begin{array}{c}\text { Volume } \\
(\mathbf{m l})\end{array}$ & $\begin{array}{c}\text { Spesific } \\
\text { volume } \\
(\mathbf{g} / \mathbf{m l})\end{array}$ & $\begin{array}{c}\text { Pore } \\
(\mathbf{1 - 5})\end{array}$ & $\begin{array}{c}\text { Symmetry } \\
(\mathbf{1 - 5})\end{array}$ & $\begin{array}{c}\text { Texture } \\
(\mathbf{1 - 5})\end{array}$ & $\begin{array}{c}\text { Hardness } \\
(\mathbf{2 4 h})(\mathbf{g})\end{array}$ & $\begin{array}{c}\text { Hardness } \\
(\mathbf{7 2 h})(\mathbf{g})\end{array}$ \\
$\mathbf{G S F}$ & & & & & & \\
\hline GWF & $144.25 \pm 3.92^{\mathrm{c}}$ & $357.50 \pm 36.15^{\mathrm{a}}$ & $2.48 \pm 0.26^{\mathrm{a}}$ & $4.05 \pm 0.77^{\mathrm{b}}$ & $3.97 \pm 0.80^{\mathrm{b}}$ & $3.81 \pm 1.00^{\mathrm{b}}$ & $550 \pm 352^{\mathrm{c}}$ & $1240 \pm 804^{\mathrm{b}}$ \\
GRF & $145.00 \pm 4.31^{\mathrm{b}}$ & $353.75 \pm 38.52^{\mathrm{a}}$ & $2.44 \pm 0.27^{\mathrm{ab}}$ & $3.86 \pm 0.69^{\mathrm{c}}$ & $3.96 \pm 0.88^{\mathrm{b}}$ & $3.67 \pm 0.73^{\mathrm{c}}$ & $687 \pm 254^{\mathrm{b}}$ & $1177 \pm 825^{\mathrm{b}}$ \\
GGLF & $147.75 \pm 3.20^{\mathrm{a}}$ & $355.00 \pm 35.05^{\mathrm{a}}$ & $2.40 \pm 0.25^{\mathrm{b}}$ & $4.81 \pm 0.18^{\mathrm{a}}$ & $4.94 \pm 0.09^{\mathrm{a}}$ & $4.73 \pm 0.24^{\mathrm{a}}$ & $958 \pm 382^{\mathrm{a}}$ & $1555 \pm 662^{\mathrm{a}}$ \\
\hline Addition level (\%) & & & & & \\
\hline 0 & $150.67 \pm 1.03^{\mathrm{a}}$ & $386.67 \pm 5.16^{\mathrm{a}}$ & $2.57 \pm 0.04^{\mathrm{b}}$ & $4.84 \pm 0.06^{\mathrm{a}}$ & $4.94 \pm 0.07^{\mathrm{a}}$ & $4.73 \pm 0.08^{\mathrm{a}}$ & $1101 \pm 49^{\mathrm{a}}$ & $2470 \pm 65^{\mathrm{a}}$ \\
5 & $141.17 \pm 2.40^{\mathrm{d}}$ & $387.50 \pm 5.24^{\mathrm{a}}$ & $2.75 \pm 0.07^{\mathrm{a}}$ & $4.43 \pm 0.45^{\mathrm{b}}$ & $4.65 \pm 0.19^{\mathrm{b}}$ & $4.42 \pm 0.43^{\mathrm{b}}$ & $432 \pm 165^{\mathrm{b}}$ & $920 \pm 203^{\mathrm{bc}}$ \\
10 & $144.17 \pm 1.47^{\mathrm{c}}$ & $339.17 \pm 11.58^{\mathrm{b}}$ & $2.35 \pm 0.06^{\mathrm{c}}$ & $4.17 \pm 0.63^{\mathrm{c}}$ & $3.78 \pm 0.88^{\mathrm{c}}$ & $3.83 \pm 0.92^{\mathrm{c}}$ & $644 \pm 269^{\mathrm{a}}$ & $1023 \pm 588^{\mathrm{b}}$ \\
15 & $146.67 \pm 2.34^{\mathrm{b}}$ & $308.33 \pm 8.16^{\mathrm{c}}$ & $2.10 \pm 0.08^{\mathrm{d}}$ & $3.52 \pm 0.80^{\mathrm{d}}$ & $3.78 \pm 0.95^{\mathrm{c}}$ & $3.30 \pm 0.90^{\mathrm{d}}$ & $751 \pm 471^{\mathrm{a}}$ & $884 \pm 318^{\mathrm{c}}$ \\
\hline
\end{tabular}

For each parameter, means with similar letter in a colomn do not differ significantly between different germinated seed flours and addition level(p<0.05). GWF: Germinated Wheat Flour, GRF: Germinated Rye Flour, GGLF: Germinated Green Lentil Flour. GSF: Germinated Seed Flour

Effect of germinated seeds and germination period on bread properties are shown in Table 6 . The lowest weight of bread was observed with GWF added samples. As statistically, similar volume values were observed in bread samples but GWF added bread samples gave higher volume values compared to other germinated seeds flour descriptively $(\mathrm{p}>0.05)$. Additionally, the highest specific volume values were observed in GWF added bread samples. The specific volume of $5 \%$ germinated seed flour containing sample was higher than control sample. The highest pore symmetry and texture scores were determined with GGLF added bread samples. But GWF and GRF addition in bread formulation gave softer crumb effect compared to GGLF addition.

After 24 hours storage, the addition of GWF showed the lowest hardness values that of the highest in GGLF. 3 days hardness values were ranged between 1177 and $1555 \mathrm{~g}$, and the lowest hardness values were observed with GWF and GRF added bread samples. After 72 hours storage of breads, the reduction in hardness occured with addition of germinated seeds flour. In fact, during storage, bread containing either 5, 10 or $15 \%$, showed lower firmness than the control sample. This might be due to reducing sugars formed during germination.

Shen et al. (2018) reported that bread prepared with fructose or sucrose had much softer crumb than bread prepared without any sugar, while the highest hardness values were exhibited with bread prepared ribose in the same baking conditions. The increase in sugar levels accompanied by decrease in starch content in cotyledons was directly linked to the activity of total amylases, which is in agreement with reports by Gupta et al. (1993). It is also considered that the fluctuations in the hardness values are caused by differences in moisture contents of bread samples.

In the bread samples with the best technological features was found with $15 \%$ addition level. A single dose (15\%) of 3 different cereal and leguminous flour (wheat, rye and green lentil) and control bread sample analysed and compared with each other for nutritional features.

Nutritional properties of bread samples fortified with $15 \%$ germinated seed flours were given in

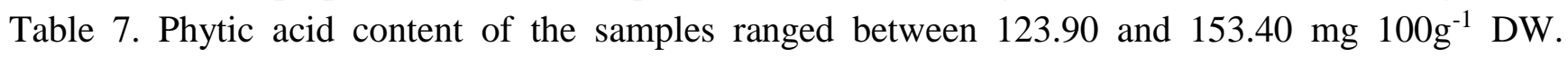
Measured amount of phytic acid decreased with germinated seed flour addition. So the highest phytic 
acid content was found in control sample. That could be the degradation of phytic acid during germination. The germinated seed flour addition was found as a significant way to degrade phytic acid and increase the total phenolic content. Total phenolic content of the bread samples made with germinated seed flours increased from 1754.5 to $2217.0 \mathrm{mgGAE} \mathrm{g}^{-1}$ dry weight. Enrichment of bread sample with GGLF gave the highest total phenolic content in bread samples. According to measurements of mineral contents, germinated seed flour addition increased the mineral content of bread samples. Especially GGLF substitution to these samples seemed to increase the potassium and iron, GRF substitution increase the calcium, magnesium, phosphorus and zinc content. Increase in nutrients (mineral content, phenolic content, amino acids, vitamins, antioxidant factors) and decrease in anti-nutrients (phytic acid, trypsin inhibitors, galactosides, saponins, tannins) after germination has been related with germination process by some researchers (Frias et al., 2005; Urbano et al., 2005).

Table 7. Nutritional properties of bread fortified with germinated seed flours

\begin{tabular}{|c|c|c|c|c|}
\hline & Control & GWF & GRF & GGLF \\
\hline Phytic acid (mg 100g $\left.{ }^{-1}\right)$ & $153.40 \pm 3.11^{\mathrm{a}}$ & $136.50 \pm 2.97^{b}$ & $132.30 \pm 2.97^{b}$ & $123.90 \pm 2.97^{b}$ \\
\hline TPC (mgGAE g $\left.{ }^{-1}\right)$ & $1754.50 \pm 13.44^{d}$ & $2025.00 \pm 42.43^{c}$ & $2109.00 \pm 41.01^{b}$ & $2217.00 \pm 46.67^{\circ}$ \\
\hline Calcium (mg 100g-1) & $53.27 \pm 0.23^{d}$ & $57.27 \pm 0.25^{c}$ & $69.57 \pm 0.18^{a}$ & $59.34 \pm 0.24^{b}$ \\
\hline Magnesium (mg $100 \mathrm{~g}^{-1}$ ) & $47.88 \pm 0.20^{d}$ & $58.68 \pm 0.09^{c}$ & $75.67 \pm 0.29^{a}$ & $59.38 \pm 0.18^{b}$ \\
\hline Potassium (mg 100g ${ }^{-1}$ ) & $235.72 \pm 0.97^{d}$ & $246.58 \pm 1.05^{c}$ & $308.89 \pm 0.90^{b}$ & $348.64 \pm 1.03^{a}$ \\
\hline Phosphorus (mg 100g-1) & $186.75 \pm 0.91^{d}$ & $203.81 \pm 1.44^{b}$ & $215.03 \pm 1.24^{a}$ & $201.86 \pm 1.05^{c}$ \\
\hline Zinc $\left(\operatorname{mg~} 100 \mathrm{~g}^{-1}\right)$ & $1.27 \pm 0.02^{c}$ & $1.65 \pm 0.03^{a}$ & $1.62 \pm 0.04^{\mathrm{ab}}$ & $1.58 \pm 0.01^{b}$ \\
\hline Iron $\left(\mathrm{mg} 100 \mathrm{~g}^{-1}\right)$ & $1.48 \pm 0.02^{c}$ & $1.40 \pm 0.01^{\mathrm{d}}$ & $1.61 \pm 0.01^{b}$ & $2.03 \pm 0.04^{\mathrm{a}}$ \\
\hline
\end{tabular}

\section{CONCLUSION}

The objective of this study was to develop functional bread enriched with germinated seed flour, and to determine its physical, chemical, nutritional and sensorial characteristics. The developed breads from wheat flour and germinated seed flour blends had higher ash, protein, TPC, mineral and lower antinutritional factor such as phytic acid compared to the control bread. Germinated rye and green lentil flour increased nutritional properties more compared to germinated wheat flour, significantly. It is quite clear that to enrich the nutritional properties of food, germinated seeds are good source, not to germinate under uncontrolled conditions.

\section{ACKNOWLEDGEMENTS}

This study was supported by the Necmettin Erbakan University Research Foundation (Project number: 161319017).

\section{Conflict of Interest}

The article authors declare that there is no conflict of interest between them.

\section{Author's Contiibutions}

The authors declare that they have contributed equally to the article.

\section{REFERENCES}

AACC, 1990. Approved methods of the American Association of Cereal Chemists, 8th edn. AACC International, St. Paul.

Ashton WM, Williams PC, 1958. The phosphorus compounds of oats. I.- the content of phytate phosphorus. Journal of the Science of Food and Agriculture, 9 (8): 505-511. 
Beta T, Nam S, Dexter JE, Sapirstein HD, 2005. Phenolic content and antioxidant activity of pearled wheat and roller-milled fractions. Cereal Chemistry, 82 (4): 390-393.

Bewley JD, Black M, 1994. Seeds: Physiology of Development and Germination. In Seeds: Germination, Structure, and Composition, Plenum Press, pp. 1-2. New York.

Ertaş N, 2015. Technological and Chemical Characteristics of Breads Made With Lupin Sprouts. Quality Assurance and Safety of Crops \& Foods, 7 (3): 313-319.

Frias J, Miranda ML, Doblado R, Vidal-Valverde C, 2005. Effect of germination and fermentation on the antioxidant vitamin content and antioxidant capacity of Lupinus albus L. var. Multolupa. Food Chemistry, 92 (2): 211-220.

Frolich W, Wahlgren M, Drakenberg T, 1988. Studies on phytase activity in oats and wheat using p-nmr spectroscopy. Journal of Cereal Science, 8 (1): 47-53.

Ghavidel RA, Prakash J, 2007. The impact of germination and dehulling on nutrients, antinutrients, in vitro iron and calcium bioavailability and in vitro starch and protein digestibility of some legume seeds. LWT-Food Science and Technology, 40 (7): 1292-1299.

Goesaert H, Brijs K, Veraverbeke WS, Courtin CM, Gebruers K, Delcour JA, 2005. Wheat flour constituents: How they impact bread quality, and how to impact their functionality. Trends in Food Science \& Technology, 16 (1-3): 12-30.

Gupta AK, Singh J, Kaur N, Singh R, 1993. Effect of polyethylene glycol induced-water stress on germination and reserve carbohydrate metabolism in chickpea cultivars differing in tolerance to water deficit. Plant Physiology and Biochemistry, 31 (3): 369-378.

Haug W, Lantzsch HJ, 1983. Sensitive method for the rapid determination of phytate in cereals and cereal product. Journal of the Science of Food and Agriculture, 34 (12): 1423-1426.

Herken EN, İbanoğlu Ş, Öner MD, Bilgiçli N, Güzel S, 2007. Effect of storage on the phytic acid content, total antioxidant capacity and organoleptic properties of macaroni enriched with cowpea flour. Journal of Food Engineering, 78 (1): 366-372.

Katina K, Liukkonen KH, Kaukovirta-Norja A, Adlercreutz H, Heinonen SM, Lampi AM, Pihlava, JM, Poutanen K, 2007. Fermentation-induced changes in the nutrition value of native or germinated rye. Journal of Cereal Science, 46 (3): 348-355.

Kayahara H, Tsukahara K, Tatai T, 2000. Flavor, health and nutritional quality of pre-germinated brown rice. In 10th International Flavor Conference, Greece, July 1-7, 2000, pp: 546-551.

Kim HY, Hwang IG, Kim TM, Wood SK, Park DS, Kim JH, Kim DJ, Lee J, Lee YR, Jeong HS, 2012. Chemical and functional components in different parts of rough rice (Oryza sativa L.) before and after germination. Food Chemistry, 134 (1): 288-293.

Kuo YH, Rozan P, Lambein F, Frias J, Vidal-Valverde C, 2004. Effects of different germination conditions on the contents of free protein and non-protein amino acids of commercial legumes. Food Chemistry, 86 (4): 537-545.

Maguire JD, 1962. Speed of germination: In selection and evaluation for seedling vigor. Crop Science, 2: 176177.

Öztürk İ, 2008. Determination of chemical properties of germinated wheat and the utilization of sprouts as a natural food additive, Erciyes University, Graduate School of Natural and Applied Sciences, Master Thesis (Printed).

Pyler EJ, 1988. Keeping Properties of Bread. In: Pyler EJ (ed) Baking Science and Technology, Sosland Publisher, pp. 2, Kansas-USA.

Quazib M, Garzon R, Zaidi F, Rosell CM, 2016. Germinated, toasted and cooked chickpea as ingredients for breadmaking. Journal of Food Science and Technology, 53 (6): 2664-2672.

Sangronis E, Machado CJ, 2007. Influence of germination on the nutritional quality of Phaseolus vulgaris and Cajanus cajan. LWT-Food Science and Technology, 40 (1): 116-120.

Shen Y, Chen G, Li Y, 2018. Bread characteristics and antioxidant activities of Maillard reaction products of white pan bread containing various sugars. LWT-Food Science and Technology, 95, 308-315. 
Skujins S, 1998. Handbook for ICP-AES (Vartian-Vista). A Short Guide to Vista Series ICP-AES Operation. Variant Int. AG. Zug. version 1.0. Switzerland.

Sung HG, Shin HT, Ha JK, Lai HL, Cheng KJ, Lee JH, 2005. Effect of germination temperature on characteristics of phytase production from barley. Bioresource Technology, 96 (11): 1297-1303.

Urbano G, Aranda P, Vilchez A, Aranda C, Cabrera L, Porres JM, Lopez-Jurano M, 2005. Effects of germination on the composition and nutritive value of proteins in Pisum sativum L. Food Chemistry, 93 (4): 671-679.

Yetim H, Öztürk İ, Törnük F, Sağdıç O, Hayta M, 2010. Yenilebilir bitki ve tohum fillizlerinin fonksiyonel özellikleri. Gıda, 35 (3): 205-210.

Zilic S, Basic Z, Sukalovic VHT, Maksimovic V, Jankovic M, Filipovic M, 2014. Can the sprouting process applied to wheat improve the contents of vitamins and phenolic compounds and antioxidant capacity of the flour. International Journal of Food Science \& Technology, 49 (4): 1040-1047. 